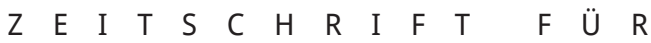

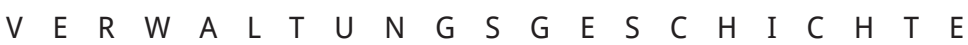

$\begin{array}{lllllllll}B & A & N & D & 4 & 2 & 0 & 1 & 9\end{array}$

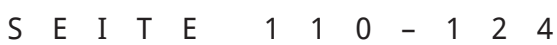

D O I : $10.2478 / \mathrm{ADH}$ I- $2019-0007$

\title{
Asking Appropriate Questions, Reconsidering Research Agendas: Moving between London and Lusaka, in- and outside the Archive
}

\author{
KIRSTEN RÜTHER
}

\section{Prelude: In Partly Disclosure}

In the earlier stages of my career, I worked on $19^{\text {th }}$-century missionary sources. I particularly dealt with the ways in which German mission societies worked themselves into South African society and learnt how they were eager to convert Africans into beings with new understandings of their selves and their social, economic and political surroundings. The missions tried to refocus the individual, and through him and her instil new meanings of everyday practices, local politics and identity in broader societal settings. A number of institutional rules existed by which the missions pursued their endeavours. The majority of these, however, were yet clad in terms of personal relations.

How much the record differs to which I have turned more recently through my work on housing policies in late colonial Zambia. ${ }^{1}$ In the record produced and moulded by the colonial state and its administration between the mid-1940s and the late 1960s, persons as well as dimensions of personhood retreated behind technocratic language, scientific thinking and a domineering planning process. At least at the first sight, the language is much drier. Similar to how Ann Laura Stoler describes her encounter with the colonial archive of the eighteenth century, the record consists of more formulaic documents, administrative epistles, curt exchanges and sometimes lengthy monthly reports. Written by district commissioners, these reports are often the most personal accounts. Stoler describes how in her work she engaged with the "product of a state in expansion and of bureaucrats eager to be viewed favourably by superiors who decided upon salaries and promotion. « I myself was often overwhelmed with information contained in the more than numerous minutes of meetings and other documents. It proved a challenge to make sense of all the details that seemed to highlight so many individual plights and complaints, but it remained a challenge to contextualise these piecemeal fragments. The colonial administration gathered and filed information and inputs of opinion. Did it also order them in a straightforward manner?

I also sensed a general distrust between individuals on the different levels and in the different sections of the apparently unconsolidated and at times unreconciled apparatuses of government and administration. On the levels of both local and central governments, however, 
European addressees of rule were eager to assert the privileges of settlers and set the worth of local and intimate knowledge of the African against the perceived intrusion from a colonial metropole deemed distant or from academic experts harbouring other aims than the pure consolidation of white privilege. Such actors were deemed sexternal and out of touch with the realities and necessities on the ground. Different from Stoler, I dealt with the product of a state veering towards development, rationalising its increased interest of extracting labour and benefits by propelling the idea of providing social welfare. Moreover, I encountered the correspondence of a metropolitan state in need of (economic and social) recovery from war ravages back home. The state was eager to legitimise its rule over Africans to both the international community (and its developing institutions) and the African population itself. To maintain and reorganise rule in a changing colonial setting, it needed data, scientific knowledge and an administrative apparatus to manage all this.

Why do I start like this? I think one can start a new research project. As regards knowledge acquisition, however, one can never start from scratch. My previous research trajectory fed into my newer research different as it was from previous projects. Against this backdrop, it is perhaps not really surprising that I ended up identifying individuals' contributions to easing the administrative process into the social and political worlds of late colonial housing.

\section{Introduction}

On the following pages, I deal with the question of how issues of planning and administering late colonial housing in Zambia were passed through various parts of an encompassing, yet imperfect colonial administration and how in fragmented segments that process, the path along which it was (re)-directed and its outcomes become retraceable for the researcher. I stress that walking that path means more than finding answers to originally posed research questions. It necessitates adjusting inquiries, looking at the archival record from various angles and across archival findings of project colleagues before assigning the material its postcolonial housing for workers and civil servants in Lubumbashi (Democratic Republic of Congo), Thika (Kenya) and Livingstone/Lusaka (Zambia), we engage as a team of four in a view on housing, which extends across different colonial settings. We take less concern with the complexities of colonial administrations within one colony but emphasise administrational resonances to be detected between our case-specific research and a broader set of relevant secondary literature.

In the Zambian case study, the research path extended into the archived version of a state and its colonial bureaucracy as rendered available today in two major national archives, one in Kew (London) and the other in Lusaka. ${ }^{3}$ The knowledge of additional archives in Brussels or Nairobi came to the fore while my understanding of these two state archives gradually unfolded. Each file ordered from the depots of an archive or talked about with colleagues setting eyes on their respective archives helped imagine and contextualise how the British colonial metropole, the Northern Rhodesia Government, its Provincial Administration or Departments of Local Government plus various employers and municipalities went about housing policies - against a backdrop of related policies and planning agendas resonating with the Northern Rhodesian setting from outside.

It took time to get into the beat of the documentation. A lot of information was repetitive. There were copies of the same minutes, drafts and notes in various files operated by clerks of different echelons and in different departments and offices of one complex, not necessarily well-oiled administrative setting. As I grappled with the material, research questions specified. Mainly, I had to come to terms with a language as well as with communication and decision-taking processes of the 1940s, 1950s and 1960s that followed a technocratic impulse. From the late 1950s onwards, this technocratic impulse faced mounting political opposition by a consolidating African nationalist movement whose representatives vied for independence. Through this web, I realised that to understand the matrix of power required me to engage with the individuals representing colonial and administrative power and with those who subverted it or who transmuted it into relationships. In fact, quite a range of actors accommodated impersonal policies, and administration-instigated policies only 
worked smoothly if there were men or women, African or European, who transformed them into a relationship. This is not to deny that the bureaucratic system operated within the confines of codes of conduct and guidelines which cannot always be identified in a straightforward manner. Taking concern with bureaucratic individuals, or pairs of individuals, ready to seize opportunities will be my means to highlight certain aspects of such structures.

Jean Allman has reminded us that Africanist historians especially have contributed in substantial ways to the comparative and theoretical discussion of oral sources, agency and subjectivity. Generally accepting the power of the colonial state, they have engaged much less with a critical examination of the colonial archive and its structures and inherent weaknesses. She also has encouraged researchers to not only doubt the messages contained in archival material but also follow their track and take seriously the possibility of research engagements emerging from the archival record. They offer points of entry to the past as well, even though perhaps not in complete accordance with the research aims set up in the beginning. ${ }^{4}$ This contribution also takes inspiration from Carolyn Hamilton, who has shown the benefit of historical analysis once biographies and trajectories are attached to the objects and material evidence in archives and museum depots. ${ }^{5}$ In this sense, this article sets out to connect archival records with representatives of a colonial administration who stood behind them and who enlivened them with a capacity to reach out into the colony. Let me probe into that field of possibilities, less so by concentrating on structure and discourse of an archival documentation alone, but by watching out for individual actors who drove policies designed and implemented by a more rationalised bureaucracy as "products of state machines [...] as technologies that reproduced those states themselves. ${ }^{6}$ Let me in this way trace the logic of colonial administration and find out which questions to ask about the past of urban African housing.

Last but not least, this contribution will set out to touch upon the ways original research inquiries receive a new edge not only through encounters with the archive and learned discussions among colleagues but through interaction with people outside the immediate realm of academic pursuits. Research unfolds as researchers encounter individuals related to either the institutions holding the documents or the people knowing about the topic of investigation through lived experience. Let me stress that this article represents an early formulation of findings we are currently moving back and forth in our project. This being work in progress, I will have to refer to our blogs, preliminary project reports and personal communications that we are currently channelling into academic publications. The formulation of final results is still underway.

\section{Housing As a Theme}

Major strikes in Northern Rhodesia (1935, 1940), Kenya (1939), Ghana and other African territories had taught the British that their political and administrative grip over Africans need to change if the metropolitan centre wanted to continue extracting economic benefit from the colonies. While the Second World War still held Great Britain under sway, awareness rose that Britain ought to alter its financial commitment to the colonies. It had become necessary after the ending of the First World War already to legitimise continued foreign rule over African societies in new ways. As a result, ideas of development first grained ground. What was originally intended to reinvigorate colonialism gradually turned into the central process by which colonial elites convinced themselves that it was possible to give up colonies. ${ }^{7}$ Colonial administration never functioned perfectly, and development initiatives involved cost that the colonial metropole was unable, and unwilling, to bear.

Development, framed in notions of scientific and technological advance, depended on manageable data. In fact, "[p]ostwar imperialism was the imperialism of knowledge. ${ }^{8}$ It was, however, the imperialism of knowledge at a time of uncertainty when the need for knowledge occurred against the backdrop of a lack of theory through which the envisioned change could have been analysed and directed. ${ }^{9}$ Furthermore, the assertion of new responsibilities depended on the insertion of a more deep-reaching bureaucratic apparatus staffed by metropolitan civil servants and, depending on the colony, African government employees at various 
ranks throughout the lower echelons of this machinery. Compared to previous periods, colonial rule became designed to rest on impersonal laws, regulations and the administrative processes rather than personal networks, favours and ties between colonial servants and representatives of the so-called traditional elite. Yet, as Stoler maintains, »knowledge-acquisition is only a piece of what makes empires work. [...] The force of rule lies in producing affiliations, loyalties, and allegiances among the empire's own agents as much as the colonized. «10

In Northern Rhodesia, the provision of housing became a main topic in the 1940s. The war had necessitated increased labour input in the mining towns on the Copperbelt, where the companies accommodated their workforce - not always to the satisfaction of the colonial power. While the mining corporations sought profit and control over workers, the British colonial administration favoured a slightly more paternalist exercise of rule and was basically "questioning the morality of handing over control of its people to a foreign profit-making company. «11 Both employers and companies were united, however, in their desire to quell disturbance and unrest. The Colonial Office turned this into administrative initiative. After the ending of the Second World War, their determination grew to move away from the erection of temporary buildings towards providing permanent dwellings. Significantly, durability became an even more important moment of discourse than concerns of hygiene, which had dominated discussions and arguments in previous decades and which continued to dominate elsewhere to effectuate a moral discourse of docility. ${ }^{12}$ Such administrative determination did not emerge out of the blue. Building styles derived from experiences previously made in India. From their commitment there, the colonial metropole had also perfected a vision of modernity according to which it was not necessary to build in standards the engineering profession could have achieved. Instead, the colonisers had arrived at promoting a "making-do mentality«: they built a lot and according to often monotonous prototypes. Such "utilitarian structures seemed to speak of a collective ideal of temporary sacrifice for the sake of some greater future objective.«13 This was an important administrative logic unfolding in Northern Rhodesia as well. The British colonial state drew on strategies of rule and design developed elsewhere in its wide imperial territory.

To achieve a more sstabilised workers in towns in the 1950s, the idea was to erect family housing rather than continue with hurdling up workers in dormitories and hostels. ${ }^{14}$ In Northern Rhodesian towns such as Livingstone and Lusaka, state and administration were too weak to evict if people sought shelter elsewhere when such family housing lacked. Local Government tended to accept the existence of so-called "unauthorised settlements" when no alternative was available. ${ }^{15}$ This itself was an indication of an administration that did not command the logistics to actually send people to the rural areas or dump them on infrastructurally unprepared ground. The argument will be taken up further below as other governments were less hesitant about urban removals.

In 1948, the Housing Act was passed in Northern Rhodesia. It decreed that employers were responsible for housing their workforce. Most employers in Lusaka and Livingstone, however, were unable or unwilling to sink large sums of money into the provision of housing. Soon the state and local governments stepped in. They built the houses - never enough, though - and made employers pay rent for their workforce. ${ }^{16}$ This was an almost feudal principle of tying a worker to his employer and a gesture of colonial control in terms of paternalism. Once people lost their jobs or retired, they stood bare of entitlement to the rooms and houses they inhabited. The whole system rested on a pre-war logic when labour migration from the rural areas had subsidised the emergence of industrial hubs. Worker's physical and mental reproduction was meant to take place in the rural areas rather than in the towns, so that companies were in a position to pay sub-economic wages to supposedly temporary migrants. The so-called stabilisation represented a policy to make men return to the villages, where men could marry and establish households. ${ }^{17}$ As colonial Zambia remained a low-wage economy, the majority of workers, even when their urbanisation was no longer frowned upon, remained utterly unable to pay their own economic rents. State and employers kept them dependent. The archival record bursts with discussions and regulations about rent. This discussion involved many parties. It touched 
upon labour issues, questions of town planning and land utilisation and required the insights of a variety of departments, such as the Public Works Department, the Town Planning Department, the Department of Health and Medical Affairs, the Department of Labour, Local Government as well as the Development and Finance Departments. This did not necessarily make planning straightforward. A fully srationalised bureaucracy would have looked differently.

Generally, the provision of housing focussed on the semerging respectable class of labourers and their families. It was not a means to alleviate the poverty of the masses who had to continue fending for themselves. ${ }^{18}$ African civil servants, in turn, started to lay claim to privileged housing and distinct residential areas. They remained mobile just like their metropolitan 'peers and moved places if they were posted to other parts of the country. Usually their ambition was to be accommodated near the European quarters rather than in the midst of an unprivileged African township. They started to feel entitled to the privileges Europeans enjoyed - an expectation they would pursue after independence within a socioeconomic context, which did not necessarily mean that it had become easier to pursue such ambitions. The "archive« telling us of such ambitions consists of memoirs and life-writings of an aspiring social class in Zambia - important to be taken into consideration but not held in the state archives under review. ${ }^{19}$

\section{Getting Started at the National Archives in Kew}

There is a lot on late colonial housing policies in the metropolitan archives in Kew, where for practical reasons rather than strictly methodological ones I started research. The place was nearer, and I was able to commence before funding for the lager project became available. Minutes, telegrams, reports of both formal and informal discussions, loads of correspondence, extracts from letters or applications for posts make up the polyphony of matters through which policies, knowledge and their communication were orchestrated. Central to making housing policies, knowledge accumulation and its dissemination work was the establishment of a research post for experimenting with material and defining building standards. Nearly two dozen specialist advisers and consultants in areas such as social welfare, labour, economics and cooperation boosted the Colonial Office after the war. In all these fields, technical and research services increased substantially. ${ }^{20}$ As regarded housing and the construction sector, great emphasis was put on developing experimental building techniques and their dissemination. ${ }^{21}$ The metropolitan archival record reveals an almost excessive debate on materials - thus indicating the importance of planning, engineering and architecture. This activism was less indicative of an already achieved transformation of bureaucracy, however, but rather one of concerted efforts towards a new, smodern and fairly encompassing style of colonial governance. However, also the future housing and building advisor would have to act within the constraints of late imperial politics. In 1949, he actually discouraged the use of prefabricated structures in the tropics. The import of such material was too expensive and hardly suited the climate. However, Britain needed to stimulate its own economy. Since the mid-1950s, a renewed emphasis on prefabricated structures to be exported from the metropole was promoted despite better knowledge. ${ }^{22}$

The Colonial Liaison Officer was appointed to the Department of Scientific and Industrial Research's Building Research Station. ${ }^{23}$ The Governments of Northern and Southern Rhodesia and Nyasaland previously had approved of a similar appointment of their own. They hoped for a regionally active specialist housing officer in Central Africa who "would only be concerned with research to a minor degree, as large part of his duties would be to travel and advise employers in the three territories. ${ }^{24}$ As far as the colonial territory was concerned, research could have been arranged through the state-funded National Building Research Institute in South Africa, which had been set up in Pretoria in 1942. After the installation of apartheid as a political system in South Africa, however, the cooperation was dropped, and the metropolitan liaison officer came into play. In her account of the production of socially relevant anthropological knowledge of the Rhodes-Livingstone Institute, Lyn Schumaker refers to the South African academic context as well, to which was linked newly emerging anthropology in colonial Zambia. After the introduction of apartheid, connections 
in terms of the employment of academic personnel from South Africa still mattered. The intellectual ties, however, shifted towards Northern Rhodesia itself, and later to Manchester. ${ }^{25}$

In his responsibility as Colonial Liaison Officer, George Atkinson became a critical figure in managing, creating, processing and sharing knowledge about the building of houses in the colonies. Without him, whose "appointment was in the nature of an experiment, $«{ }^{26}$ late colonial knowledge production would not have worked the way it did. In the application process, Atkinson succeeded against a competitor who »impressed the Board as being rather set in this ways and likely to be somewhat autocratic and intolerant of other people's opinions, [and who] would not make a good impression upon Colonial Governments. « ${ }^{27}$ To cooperate with the colonies required determination, while at the same time, it was a sensitive issue. Atkinson was expected to "make a good impression on the Government officials with whom he may come into contact. « ${ }^{28}$

In his daily routines, he responded to both postal enquiries and personal visits of Colonial Officers. He established an information service by means of which a variety of information bearing on colonial building problems was brought to the notice of recently appointed colonial correspondents. Atkinson studied house designs in hot climates and inquired into town planning legislation, the behaviour of new building materials under tropical conditions and the use of local resources, and committed himself to many more matters. ${ }^{29}$ Organising the circulation of knowledge across the Commonwealth, he transcended the boundaries of purely technological and building research. He showed himself particularly prepared to devote "half his time to general questions concerning housing in a ssocial service sense. $\aleph^{30}$ Against the backdrop of specialising fields of knowledge and policies, he created his own sphere from which to interact with numerous experts and across scientifically or administratively pre-figured compartments of changing colonial rule. At the same time, he was a >modern ‘ colonial bureaucrat. By disseminating standards and knowledge, he assumed that crucial administrative and technological responsibility to ensure that British standards, methods and business relations would permeate ordinary life, politics and procedures of the becoming post-colonies. ${ }^{31}$ allocation of funds and programmes, a field in which a personality such as him would probably have been needed to ensure the workings of the new policy design in far-away geographical settings. As I learnt from my project colleague, Martina Barker-Ciganikova, George Atkinson made his way to Kenya, ${ }^{32}$ yet as far as I have been able to reconstruct he never visited colonial Zambia. In the archival record at least, as regarded information about physical visits, he left indirect traces only.

The allocation of funds was another sphere of crucial administrative activity. The Colonial Office was prepared to have the Northern Rhodesia Government launch schemes for home ownership through which they hoped to prompt the "emergence of a property-owning class of Africans." Related to this aim, they were also prepared to start an "Owner Housing Loan Scheme. ${ }^{33}$ Northern Rhodesia, however, was determined that "no money will be lent to Africans. ${ }^{34}$ Loans would be made available to local authorities for building permanent houses. It remained imperative, however, that these houses were "for renting to employers (repeat employers) as stated in my telegram no. $300 . \aleph^{35}$ Additional funds for a pilot scheme of 70 houses to be owned by Africans were made available from London, but I have not been able to trace where, when and how these funds were channelled into a respective project. There were telegrams and funds in one direction, but if nobody took them up at the other end, not much came out of it. Administrative procedures and formulated policies alone were not sufficient, particularly not in a context where the colonial administration played the politics of delay. I will return to this in the subsequent section.

These were some of the starting points identified in Kew. How would they relate to the archival threads retraceable in Lusaka?

\section{Interlude: Personal Communications in Archival Settings}

"What is your church?» The two young men chuckled as they asked me the question. Their names were Lukas and Thomas, and they were lower staff of the archive. 
We got to know each other by our first names and church affiliations. ${ }^{36}$ We never talked about surnames. They were Lukas from the Assemblies of God Church and Thomas from the Catholic Church. As I did not have a church affiliation, I became Kirsten from Vienna in Austria to them. Lukas, Thomas and I were standing outside the main entrance of the National Archive in Lusaka, where in the inner courtyard, a huge and meanwhile disused signboard announced that this was »The Memory of the Nation « (outside the premises there were more smodernised announcements focusing on the services available at the Archives today.) I had just registered as a user and started to browse through the inventories and other finding aids. I was still in the process of getting adjusted. »Well, yes, you know [...],«I started to explain in an awkward tone as I was unsure whether I should tell them that I had no church. "Oho," they interrupted me leaning back in a relaxed posture, »We already know what you want to say. Religion does not matter where you come from?« I could neither tell them anything new nor shock or surprise them. They just shook their heads in disbelief and probably enjoyed me hem and haw around. ${ }^{37}$

Encounter is knowledge, is getting to know each other. The ice was broken. I would be welcome to join them on Sunday at the Catholic Church or for one of the Assemblies of God services. Would I come? Ann Laura Stoler has drawn our attention to the importance of personalised accounts to get a fuller grasp of administration and bureaucracy. She made use of letters exchanged between "a lowly civil servant stationed on the north Bali coast « and his far-away daughter back in the Netherlands and read them as "personalised inflections. ${ }^{38}$ In my own research, personal encounters and the exchange of views, always shifting the temporal perspective to the present, have always mattered in the process of knowledge generation. All through my South African research - and in my Zambian research now as well - I have benefited extremely from coming across the "knowledgeable communities" scholars of cultural studies have written about with so much insight. ${ }^{39}$ Lukas from the Assemblies of God Church and Thomas from the Catholic Church established ties. Ever after that first encounter, they made sure that I was always helped when ordering 'my< files. At times, they also stored files in corners where the other staff members would not find them immediately the next morning - so that I virtually depended on them.

This is more than an anecdote. These two men's interference alerted me to the importance of individuals in the bureaucratic process. The rules of the archive were well set up. They worked well. However, it were Lukas from the Assemblies of God Church and Thomas from the Catholic Church who in their profession as archive staff members made them work out in a particular way that shaped my experience in the archives. They co-created the scope and the space of my daily working projects, accommodated my research path in a particular way. I started to watch out more carefully for individuals under the techno-scientific administrative acts from then on.

The encounter also helped me to reassess my visit to the National Archives in Kew. They were also much more than a building, signposts and institutional architecture. ${ }^{40}$ An archive may be understood as a political imaginary. ${ }^{41}$ It may be dedicated "to documenting, supporting and promoting greater awareness of past and contemporary struggles for justice through archival practices and outreach. « ${ }^{42}$ In both Lusaka and Kew, the archives were places of encounter between people with the most various interests in the past. Both here and there, archives were places of encounter between users and persons who represented the rules and the institution. In the National Archives in Kew, I always carried a colourful notepad with me for taking handwritten notes. After the second or third day, whenever in the morning I entered the large reading room through the turnstile and had my belongings checked by the personnel, there was an extremely solicitous elderly employee, whose name I never got to know, but who commented with a regularity that could soon be foreseen, "Oh, I remember, the lady with the peacock design on her booklet. Oh yes indeed, indeed. What a lovely design. «33 It was a polite acknowledgement that he recognised me and - perhaps - did not really suspect me of wanting to cheat and smuggle something forbidden inside. The strict regulations in fact allowed users to carry pencils only. By acknowledging the peacock design on an almost daily basis, he made me smile for a few seconds each day before I got to work. Even though in that space as a user I was submitted to strict controls, I did feel neither dominated, intimidated, surveyed nor bullied around - 
even though there was in fact a lot of surveillance. I felt assured, however, that this elderly gentleman would make all the rules as bearable as possible. This means that even before opening the first file produced by a modernising colonial bureaucracy, I had encountered a person who implicitly reminded me of there being individuals who are the face of any such bureaucracy and its archived version.

of course, such perceptions and interpretations depend on the research inquiries one is occupied with. Caroline Elkins, who has worked on the violent character of repressing Mau Mau and on the pains of not letting this part of Kenyan history emerge into a sphere of memory, describes the National Archives at Kew - quite in contrast - as an "uncluttered interior governed by a hyper-monitoring system, identification cards, assigned seats, routinized systems for ordering and holding documents, proficient archivists, and security checkpoints. ${ }^{44}$ She has a point characterising the working atmosphere as one of "benign efficiency." There resides a certain ruthlessness in this kind of environment, Elkins suggests. Talking about remarks on peacock-patterned notepads, as I just did, is not intended to downplay the colonial frame within which users of the National Archives move. However, it is worth of note that with a crucial Kenyan historical experience in one's back, the archive is likely to deliver other aspects of its nature than if one comes there with research questions pertaining to tendentially less violent historical settings or to settings where imminent colonial violence did finally not erupt as compared to Kenya's Mau Mau. In such a case, other facets of the encounter form prominent part of the picture - even though they do not abrogate the deeply ingrained colonial inequality and sense of exclusion breathing in this building.

\section{Bureaucratic Individuals Seizing Opportunities}

The material one encounters in the National Archives in Lusaka was overwhelming. There were minutes, reports, correspondences, many newspaper clippings and photographs. George Atkinson hardly figured. It remained generally difficult to identify individual or techno-scientific processes into some project of their own. In other places, fellow researchers have come across such figures in a few instances. There was Ernest Albert Vasey in Nairobi, Kenya's Minister for Local Government in the early 1950s. It was him, in close connection with J. H. Thomas, the first appointed local housing officer, and a civil servant of the lower echelons who each according to his respective predispositions, envisioned, implemented, guarded and reported on the first homeownership housing scheme in post-war Thika, a small township near Nairobi. Homeownership schemes represented an adjunct to municipal housing projects rather than an alternative. On this pilot project, Thomas was the one to cooperate closely with African counterparts. He also selected future residents and debtors eligible for the related loan scheme. ${ }^{45}$ Martina Barker-Ciganikova argues that it needed a visionary and a practitioner working closely with African counterparts to launch and maintain the scheme over the initial years. Fraught with expectations and the ensuing setbacks, the project rendered visible some of the more general possibilities the colonial administration facilitated. While the outcomes of the project cannot be reviewed here, the project's existence itself alludes to the necessity of some bureaucrats being prepared to get involved and work the administrative thread into something visionary as well as material.

In Livingstone, there was a parallel figure to J. H. Thomas. His name was R. A. Beaton, who acted as Location Superintendent in Maramba compound and, in later years, as Chief Officer of African Affairs. ${ }^{46}$ Beaton was an intermediary with "great experience of local conditions and goodwill. « ${ }^{47}$ He lacked a scounterpart such as Ernest Vasey, however. He also did not formally cooperate with Africans whose housing he administered. Nothing significant came out of his power and supposed popularity.

This had been once different with a bureaucrat such as Eric Dutton, who jointly with Ajith Singh, Indian civil servant in both Zanzibar and postcolonial Malawi, managed to direct and design urban spaces in Zanzibar, Nairobi and Lilongwe. In the 1930s - before the provision of African housing took off in Northern Rhodesia - he had entertained "a kind of administrative menage a trois" with Northern Rhodesia's Governor 
Hubert Young and his Chief Secretary Charles Dundas. ${ }^{48}$ As part of this triad and in his function as head of the government financial commission, Dutton got heavily involved in procuring funds for the new capital, Lusaka. He also crucially facilitated communication with Livingstone's settlers, who were hostile to the idea of the capital being removed. Despite his lowly administrative position (inferior to both the Governor and his Chief Secretary), Dutton became a crucial player in making the administrative process work. So far I have not come across a similar figure for the period after the 1940s.

In Lubumbashi, a mining centre in the Katanga region of the Belgian Congo, it is possible to look at District Commissioner Ferdinand Grévisse's scheme of giving incentive to working class families building their own houses. In an authoritarian setting, never designed to become more liberal, Grévisse fervently promoted the idea of the municipality buying building materials in bulk for Africans who would subsequently construct their homes under close supervision and according to a predefined list of restrictions and obligations on technical issues. The scheme, which can be credited for pushing homeownership possibilities, was intended less to promote the emergence of a new and self-reliant middle class but rather to enframe and welt workers who were expected to remain docile. Against substantial criticism, Grévisse pushed his initiative into a longlasting project. Africans were excluded from decisionmaking, but they acted as builders. ${ }^{49}$

In Bulawayo, Southern Rhodesia, yet again, Hugh Ashton, Director of the newly erected African Administration Department, self-confidently turned the city's African housing policies into a project that differed substantially from the capital Salisbury's procedures. Jointly with African staff trained in his department, with trade union leaders and major representatives of the Rent Payers Association, he pushed for the establishment of housing schemes in various becoming suburbs of Bulawayo. ${ }^{50}$ While Terence Ranger stresses the roles and initiatives of Africans, Maurice Hutton credits Ashton as being the central figure in achieving the cooperation of the numerous parties in his schemes. ${ }^{51}$ Irrespective of the final evaluation, it would make sense, however, to ssuspect at least a minimum of African involvement in turning such government housing schemes into a liveable reality.
The importance of African clerks, interpreters and more unspecialised intermediaries in the facilitation of colonial rule has been noted in other contexts. ${ }^{52}$ It is not a coincidence, however, that these frequently refer to either West African colonial settings or missionary endeavours. Read in conjunction, the above-mentioned case studies show that settler scenarios slightly differed and, as long as situations were not characterised by heightened conflict and resistance, usually required the involvement of strong or well-meaning European counterparts willing to bond with African mediators. What they pushed in terms of society could differ significantly. While at times the emergence of a property-owning class ready to assume the takeover of a so-called social responsibility was imagined, in other instances, the blunt disciplining of workers represented the ultimate aim. Both envisaged outcomes could be subsumed under the idea of development. Both were indicative of an administrative apparatus in change, which opened windows for bureaucrats to press forward personal convictions.

For the researcher, this implies to refer to sources outside officially instituted archives. Clues towards grasping the eminence of Africans in such procedures of making formal administration work can sometimes be found in personalised archives, some of which Karin Barber has focussed on. She argues that it is particularly revealing to use such shidden เ archives so as to engage with their guardians' personality and self-conceptions. ${ }^{53}$ One could also think of the wives and female companions of male Indian nationalists literally dwelling in the archives when storing documents of their husbands' political commitment in the very houses the female part of the families occupy. ${ }^{54}$

Colonial Zambia, at that time Northern Rhodesia, did not leave the scope for individual bureaucrats seizing opportunity. Even though the state could have relied on ground-breaking research by the RhodesLivingstone Institute, these insights that in the academic sphere helped bring about a new understanding of African urban environments only gained acceptance among government planners partially and very slowly. Census methods, for instance, were more accurate with the Rhodes-Livingstone Institute as compared to the government even though the technological innovation of the state and the mining companies made them invest in 
computer technology and calculation machine superior to what the academics relied upon in the 1950s. The lack of recognition was partly due to rising political tensions in the colony and partly a result of rivalries about who was the expert on Africans in urban surroundings. ${ }^{55}$ The Northern Rhodesian bureaucracy sent delegates to regional conferences on building technology and labour questions. These conferences were attended by colonial bureaucrats from many African countries under British rule. Sometimes the delegates stayed one or two days longer for the so-called informal meetings. Whereas the official parts of these conferences were often devoted to imperial show-offs, the informal meetings had a more practical design. Bureaucrats consulted colleagues about how they went about implementing certain rules and innovations. ${ }^{56}$

Despite the racist character of rule in Northern Rhodesia, there were a number of liberally minded individuals notimmediately aligned with the harsh settler racism of the time. They tried to act as interlocutors for the upcoming new African elite. Quite generally, there was a basic distrust of settlers and local administrators with regard to metropolitan political interferences and staff. The staff from Britain, in turn, often trained at elite institutions such as Oxford or Cambridge, well-paid and endowed with the privileges of expat civil servants, were a mobile force on secondment in the colony, not necessarily for the rest of their lives. Many of them did, in fact, leave Zambia once it became independent. ${ }^{57}$ Yet none of them went as far as to launch a distinct housing project that could have been created out of the structures, funds and incentives prompted through the metropolitan Colonial Office. Emmanuel Mutale in his study on urban management has a clear sensorium for the ways individual administrators and office bearers mattered for pushing the administrative process. He names a number of town planning engineers, chief secretaries, managing directors of mining companies and governors who corresponded with each other to take administrative decisions in conversation. According to this study, >management ` was anything but an anonymous procedure. ${ }^{58}$ At the same time, he did not identify particular individuals who would have gone beyond their prescribed roles.

I stumbled across one administrative protagonist on the spot who, like some of his colleagues, went to investigate homeownership schemes in neighbouring countries. In the end, however, they were unsuccessful to transplant such initiatives systematically to the country they had come from. ${ }^{59}$ Captured in a box of thinking in terms of rent, and employer-paid rent more particularly, there was little scope anybody could have seized in the end. Furthermore, compared to such territories as Kenya, where a law-and-order mentality was deeply rooted, the Katanga region, known for the total authority the mines exercised over their workers, or Southern Rhodesia, where settlers marginalised the rights of Africans, Northern Rhodesia's history of colonisation and of building up a bureaucratic apparatus was yet more recent. This might have made it more difficult to find African collaborators and knowledgeable interlocutors from a wider "knowledgeable community." In the towns, for instance, no rentpayers’ associations existed. Trade unions remained moderate after the succession of strikes that had once characterised the 1930s and 1940s. ${ }^{60}$ In addition, the Northern Rhodesia Government made sure that there was a check on spolitics` among the government employees. Those who were active in the welfare societies had little chance of being recruited neither for the colonial service nor for the local administrative bodies in the townships.

Like in other (British) colonial possessions, there had been a push towards reformed local government in the late 1940s. Lord Hailey's ideas of the need to prepare for possible independence became a pronounceable option even though the time perspective involved was perhaps less clear.

We are working towards the creation of African States, with African Governments, under forms determined by local conditions, in which European control or guidance will diminish until it reaches a vanishing point. In two cases at least, Kenya and Northern Rhodesia, the picture is complicated by the existence of a European resident community. ${ }^{61}$

This played out in the politics of colonial Zambia. The first Urban Advisory Councils had been established in 1938 already - albeit with no scope for interference in urban politics. In the 1950s, Urban Advisory Councils were in a position to communicate to their respective Municipal Councils various needs arising 
in African townships. Their communication, however, was not direct. Each Municipal Council afforded an African Affairs committee in which a European representative of African interests articulated the demands and recommendations of the African Urban Advisory Councils over which he presided. The whole administrative setup was rather indirect and dependent on presumably well-meaning benefactors. Needs were listened to and got acknowledged in the minutes of the meetings. That was how the delays started. The matters were repeated over and again, which may be read as a sign that not much happened on the ground even though the minutes' language suggests that they were tackled efficiently. Frequently, however, the strategy was to refer the matter to another authority that would also express determination to assess the problem in its totality and propose a solution.

On the level of central government, the scenario changed when in 1946, the territory-wide Federation of African Societies had been formed by Dauti Yamba. This umbrella organisation sought to bring various African traders' groups, shop assistants' associations, farmers' associations and welfare societies into one association. Two years later, it became the Northern Rhodesia Congress, a forerunner of the nationalist political parties. ${ }^{62}$ The African Representative Council was established in 1946 as well. This body brought together 25 Africans elected by their colleagues on the various Provincial Councils plus four appointees of the Paramount Chiefs of Barotseland. The African Representative Council was the highest consultative body in Northern Rhodesia - albeit, again, with no executive powers and presided over by the Secretary of Native Affairs. From 1948 onwards, however, it elected two Africans to sit on the Legislative Council. Like other advisory councils, the African Representative Council did not satisfy African aspirations, but membership did provide experience in democratic procedures and enabled the educated to contribute to their communities on issues such as education, sanitation and township organisation. It also provided a forum to articulate African opinion and voice opposition to the scheme of joining Southern Rhodesia, Northern Rhodesia and Nyasaland into the Central African Federation. ${ }^{63}$ Whereas the official jargon spoke of this union as based on "partnership, " they did not refrain from calling it "partner-shit.«64 Obviously, the politicisation of the setting translated into unfavourable circumstances to let emerge bureaucratic individuals prone to seizing their opportunities.

The nearest one comes to encountering such a personality was J. R. Brown, Acting Secretary of the Ministry of Local Government and Social Welfare in 1960, and Permanent Secretary of that Ministry in 1963. He and Jonathan Chileshe, member of the emerging African elite in Northern Rhodesia, had investigated housing schemes in Salisbury in 1952 and $1953 .{ }^{65}$ Between 1955 and the beginning of 1957, he chaired the commission that wrote the so-called Brown Report, which responded to pressure emerging from the increased political demands voiced in African nationalist parties. The commission, exclusively staffed by residents of Northern Rhodesia, argued in favour of an economic wage to pay an economic rent. Contrary to the expectations of the liberally minded, it refrained from recommending direct African representation - even though it did consider more active parts for Africans to play in the administration of their housing areas. ${ }^{66}$ The recommendations were hotly debated, especially among more conservative-minded politicians as they were feared as being a so-called blueprint for drawing too many unemployable Africans into the emerging towns. Daring as the report's suggestions were deemed to be against the backdrop of an ever more assertive setter population, it soon became evident that Brown prodded an ill-fated scheme that never took off. The findings of the report were never fully implemented. Interestingly, in his biography, written by his younger brother, the accompanying Safeli Hannock Chileshe spoke a lot about his own housing - even though not about his visit to any of the neighbouring schemes. He was clearly frustrated that his socially aspiring family was never credited with the housing that would have distinguished them. ${ }^{67}$

\section{Conclusions}

This contribution set out to reflect upon the administrative rules and procedures connected to late colonial urban housing policies in Northern Rhodesia, particularly as they could be read off archival material 
with regard to Livingstone and Lusaka. It turned out that although the archival record was multifaceted and abundant, it did not immediately reveal the structures of a past and smodernising colonial bureaucracy. Instead, it became manifest in various fragments and different dimensions.

To approach the complexities of this process, I not only gained insights from ongoing conversations with colleagues occupying themselves in a larger research project with similar questions in respective case studies of other colonial settings but also drew on conversations with archival staff in various places. Their commitment and willingness to establish communicative ties alerted me to the crucial fact that institutions and administrative procedures sliver from staff and specialists, a knowledgeable community seizing opportunities. Such individuals are not able to alter the structures, but they matter significantly with regard to whether a system's capacities can be tapped. It does not need emphasising that such individuals may trigger 'good، as well as bad outcomes of the system.

Between the late 1940s and early 1960s, colonial Zambia lacked such individuals. This partly was a result of the racist and unopen colonial situation, and a general weakness of the state and its administrative apparatus. Successful or at least partly innovative urban housing schemes depended on the initiative of bureaucrats who managed to connect their zeal and wish to mould and frame to African or mediators' skill and readiness to partake in such ventures.

The gathering of knowledge with regard to the planning, implementation and meaningful unfolding of late colonial housing schemes in African towns therefore takes researchers not just straight away into a set of rules and regulations. It requires us to engage with individuals and personalised group constellations within which such rules and regulations achieved societal impact. While we are engaging with that component, we are permanently asked to adjust our research questions. The adjustment of these questions will keep our mind open. 
1 This contribution was written as part of the FWF-granted project "Employment-tied Housing in (Post)colonial Africa» (Project no. P29566-G28). For further information see https://housing.univie. ac.at. I would like to extend thanks to three anonymous reviewers whose comments helped to shape the argument of this article.

2 Ann Laura Stoler: Along the Archival Grain. Epistemic Anxieties and Colonial Common Sense, Princeton, NJ 2009, p. 232.

3 In Ndola, the archives of Zambia Consolidated Copper Mines are housed. They are particularly important with regard to housing in mining compounds and adjacent African towns. Issues of Copperbelt housing are taken into consideration through the use of secondary literature. No primary research is intended on this kind of housing within our three-year project which for the Zambian case focuses on Livingstone and Lusaka.

4 Jean Marie Allman: Phantoms of the Archive. Kwame Nkrumah, a Nazi Pilot Named Hanna, and the Contingencies of Postcolonial History-writing, in: American Historical Review 118/1 (2013), pp. 104-129, at p. 107.

5 Caroly Hamilton: Backstory, Biography, and the Life of the James Stuart Archive, in: History in Africa 38 (2011), pp. 319-341.

6 Stoler: Along the Archival Grain, p. 28.

7 Frederick Cooper: Modernizing Bureaucrats, Backward Africans, and the Development Concept, in: Frederick Cooper / Randall Packard (eds.): International Development and the Social Sciences. Essays on the History and Politics of Knowledge, Berkeley, CA 1997, pp. 64-92.

8 Cooper: Modernizing Bureaucrats, p. 64.

9 Frederick Cooper: Development, Modernization, and the Social Sciences in the Era of Decolonization. The Example of British and French Africa, in: Revue d'Histoire des Sciences Humaines 10 (2004), pp. 9-38, at p. 10.

10 Stoler: Along the Archival Grain, p. 253.

11 Emmanuel Mutale: The Management of Urban Development in Zambia, London 2004, p. 90.

12 See difference in the Belgian Congo, for instance, Daniela Waldburger: House, Home, Health and Hygiene - Social Engineering of Workers in Elisabethville / Lubumbashi (1940s to 1960s) through the Lens of Language Usage, in: Martina Barker-Ciganikova / Kirsten Rüther / Daniela Waldburger (eds.): Accommodating Workers and Urban Residents. The Politics of Housing in (Post)Colonial Africa, Munich 2019 (in print).

13 Peter Scriver: Empire-building and Thinking in the Public Works Department of British India, in: Peter Scriver / Vikramaditya Prakash (eds.): Colonial Modernities. Building, Dwelling and Architecture in British India and Ceylon, Abingdon: Routledge, 2007, pp. 69-92.

14 Robert K. Home: Of Planting and Planning. The Making of British Colonial Cities, Oxford 2013, p. 186.

15 Kirsten Rüther: The Rule of Rent. The State, Employers and the Becoming Urban Dweller in Northern Rhodesia Acting across a Societal Field of Force, c. 1948-1962, in: Martina Barker-Ciganikova / Kirsten Rüther / Daniela Waldburger (eds.): Accommodating Workers and Urban Residents. The Politics of Housing in (Post) Colonial Africa, Munich 2019 (in print). Different attitudes emerged in the Southern Rhodesian context, especially in Salisbury (Harare) and Bulawayo, where the state was stronger and in a more solidified position to exercise power over Africans in town.

16 Carole Rakodi: Colonial Urban Policy and Planning in Northern Rhodesia and Its Legacy, in: Third World Planning Review 8/3 (1986), pp. 193-217.

17 Helmuth Heisler: Urbanisation and the Government of Migration. The Inter-relation of Urban and Rural Life in Zambia, London 1974, pp. 77-91.
18 Karen Tranberg Hansen: Distant Companions. Servants and Employers in Zambia, 1900-1985, Ithaca, NY 1989, p. 120.

19 Kirsten Rüther: Their Fathers Were Bricklayers, Carpenters and Employees of the Public Works Department. Notions of Social and National Advance in the Zambian Life-writing, in: Journal of Commonwealth Literature (2020, forthcoming).

20 Joseph M. Hodge / Gerald Hödl: Introduction, in: Joseph M. Hodge / Gerald Hödl / Martina Kopf (eds.): Developing Africa. Concepts and Practices in Twentieth-Century Colonialism, Manchester 2014, pp. 1-34, at p. 15.

21 Jiat-Hwee Chang: A Genealogy of Tropical Architecture. Colonial Networks, Nature and Technoscience, Abingdon, NY 2016, p. 169.

22 The National Archives (Kew) [NAUK], Colonial Office [CO] 1015/1873: Prefabricated Houses for Africans, 1957-1959; CO 1015/2500: Prefabricated Houses for Africans, 1960-1962; Chang: Genealogy, p. 191.

23 The institution existed since 1921 at East Acton, near London.

24 NAUK, CO 795/147/6: Central African Council, Standing Committee on African Housing, report 19. 11. 1946 and minutes of a meeting 25. 11.1946.

25 Lyn Schumaker: Africanizing Anthropology. Fieldwork, Networks, and the Making of Cultural Knowledge in Central Africa, Durham / London 2001, pp. 1-21.

26 NAUK, CO 927/131: Building Research. Appointment of Colonial Liaison Officer to D.S.I.R. Building Research Station, 1951-1952, file summary at the beginning of the record, 4. 6. 1952.

27 NAUK, CO 927/35/5: Proposed Colonial Housing Bureau. Appointment of a Colonial Liaison to the D.S.I.R. Building Research Station, 194648, Mr. Butters to Mr. East, correspondence 17. 1. 1948.

28 NAUK, CO 927/35/5: Proposed Colonial Housing Bureau, correspondence 17. 1. 1948.

29 NAUK, CO 927/35/7: Building Research. Appointment of a Colonial Liaison Officer to D.S.I.R. Building Research Station, 1949, extract from a letter received from the Director, D.S.I.R. Building Research Station, Garston, Watford, 23. 11. 1948.

30 NAUK, CO 927/131: Building Research. Appointment of a Colonial Liaison Officer, remark on the summary pages opening the file, 4. 6. 1952.

31 Due to one reviewer's comments, I learnt that Atkinson's influence transcended the British Empire. At least one of his texts on how to build in the tropics was translated into French and published in a theme issue of a Belgian architectural journal devoted to building in the Belgian Congo. Thanks go to the reviewer for this input.

32 Personal communication Martina Barker-Ciganikova, in our project session on 10. 4. 2019. Martina Barker-Ciganikova researches the Thika case study, see https://housing.univie.ac.at/case-studies/.

33 NAUK, CO 1015/1154: Proposal to Grant Loans to Purchaser in Northern Rhodesia, 1954-1956, Colonial Office Government House, Lusaka, to Secretary of State for the Colonies, London, 8. 11. 1956.

34 NAUK, CO 1015/1193: African Housing in Northern Rhodesia, 19541956, inward telegram from Northern Rhodesia (Sir Arthur Benson) to the Secretary of State for the Colonies, 10. 7. 1955.

35 NAUK, CO 1015/1193: African Housing, inward telegram, 10. 7. 1955.

36 The first names are pseudonyms. The names of their churches are not.

37 Personal research diary, July 2017.

38 Stoler: Along the Archival Grain, p. 263.

39 Karin Barber: Preliminary Notes on Audiences in Africa, in: Africa 67/3 (1997), pp. 347-362; Liz Gunner: Supping with the Devil. Zulu Radio Drama under Apartheid - The Case of Alexius Buthelezi, in: Social Identities. Journal for the Study of Race, Nation and Culture 11/2 (2005), pp. 161-169. 
40 Achille Mbembe: The Power of the Archive and Its Limits, in: Carolyn Hamilton et al. (eds.): Refiguring the Archive, Dordrecht 2002, pp. 19-27.

41 Bhekizizwe Peterson: The Archives and the Political Imaginary, in: Carolyn Hamilton et al. (eds.): Refiguring the Archive, Dordrecht 2002, pp. 29-37.

42 South African History Archive, online: www.saha.org.za (15. 4. 2019).

43 Personal research diary, November 2016.

44 Caroline Elkins: Looking beyond Mau Mau. Archiving Violence in the Era of Decolonization, in: American Historical Review 120/3 (2005), pp. 852-868, quote p. 852.

45 Martina Barker-Ciganikova: Let Them Own Their Own: Design and Implementation of a Colonial Housing Scheme in Thika, Kenya, 1950-1953, unpublished project manuscript (intended for publication), April 2019.

46 National Archives of Zambia (Lusaka) [NAZ], SP 4/3/5: Livingstone Municipality: Native Affairs Committee, 1945; SP 4/1/33: Municipality of Livingstone: Minutes of Native Affairs Sub-Committee Meetings, 1948 and a number of other files with records ranging from 1945 to 1958.

47 NAZ, Local Government and Housing [LGH] 3/25/17: Urban Advisory Councils, Welfare Associations General, and Other Associations, 1956-1960, May 1958.

48 Garth Myers: Verandahs of Power. Colonialism and Space in Urban Africa, Syracuse 2003, esp. pp. 55-75 on Dutton's time in Lusaka. The quote is taken from Dutton's memoir rendered in this spelling on p. 59.

49 Sofie Boonen / Johan Lagae: Ruashi, A Pessac in Congo? On the Design, Inhabitation, and Transformation of a 1950s Neighborhood in Lubumbashi, Democratic Republic of the Congo, in: Martina Barker-Ciganikova / Kirsten Rüther / Daniela Waldburger (eds.): Accommodating Workers and Urban Residents. The Politics of Housing in (Post)Colonial Africa, Munich 2019 (in print). Again, this is not the space to report on the scheme's development itself.

50 Terence Ranger: Bulawayo Burning. The Social History of a Southern African City 1893-1960, London 2010, pp. 169-180.

51 Maurice Hutton: Seeing Like a Second City. Contested Development in the African Townships of Late Colonial Bulawayo, Rhodesia, 1949-1977, unpublished PhD thesis, University of Edinburgh 2018.

52 Martin Klein: African Participation in Colonial Rule. The Role of Clerks, Interpreters, and Other Intermediaries, in: Benjamin N. Lawrance / Emily Lynn Osborn / Richard L. Roberts (eds.): Intermediaries, Interpreters, and Clerks. African Employees in the Making of Colonial Africa, Madison, WISC 2006, pp. 273-285.

53 Karin Barber (ed.): Africa's Hidden Histories. Everyday Literacy and Making the Self, Bloomington 2006.

54 Antoinette M. Burton: Dwelling in the Archive. Women Writing House, Home, and History in Late Colonial India, Oxford 2003.

55 Schumaker: Africanizing Anthropology, pp. 183-189.

56 Work in progress.

57 Pamela Shurmer-Smith: Remnants of Empire. Memory and Northern Rhodesia's White Diaspora, Lusaka 2015.

58 Mutale: Management, pp. 85-87.

$59 \mathrm{NAZ}, \mathrm{LGH}$ 1/16/57: African Housing Application of Elisabethville Housing Scheme, 1954-1956, Northern News on "Congo housing is for swell-to-dor«, 27. 9. 1954.

60 David C. Mulford: Zambia. The Politics of Independence 1957-1964, Oxford 1967, pp. 170-177.

61 Lord William Malcolm Hailey: Native Administration in Africa, in: International Affairs 23/3 (1947), pp. 336-342, at pp. 338-339.
62 Mulford: Zambia, pp. 13-17; Andrew Roberts: A History of Zambia, London 1976, p. 204.

63 This added another administrative layer to the colony. Housing, however, remained a concern of local governments.

64 Jotham C. Momba / Fay Gadsden: Zambia. Nonviolent Strategies against Colonialism, 1900s-1960s, in: Maciej J. Bartkowski (ed.): Recovering Nonviolent History. Civil Resistance in Liberation Struggles, Boulder, CO 2013, pp. 71-88.

65 NAZ, LGH 1/16/49: Housing for Eurafricans, 1949-1953, Report of the Committee to Inquire into the African and Eurafrican Housing Position in Lusaka [Nightingale Committee] sent to the Member for Health and Local Government, 5. 5. 1953.

66 NAZ, Ministry of Labour and Social Services [MLSS] 1/24/14: Employment of Natives and »Housing Conditions", 1957-1959, Mr. Botha, Nkana representative, and Mr. Sokota, African Member, in LegCo debate, Hansard 92x 7. 8. 1957; see also Rüther: The Rule of Rent.

67 Rüther: Their Fathers Were Bricklayers, in: Jonathan H. Chileshe: Alderman Safeli Hannock Chileshe. A Tribute to (the Man), his Life, and History, Ndola 1998. 


\section{Abstract}

This article deals with the question of how issues of late colonial housing in Zambia were passed through various segments and between various layers of an encompassing colonial administration. It is equally about the question how the researcher retraces that process of administering housing. The main argument is that a discourse clad in techno-scientific language in the colonial metropole assumed undertones of development and morality in the colony. The text pays particular attention to the bureaucratic individuals seizing opportunities - often in cooperation with one or two colleagues, or across racial dividing lines. Furthermore, the contribution ponders on the significance of the researcher's encounters with both archival staff in London and Lusaka as through these interactions initial research agendas become redirected and adjusted.

\section{About the Author}

Kirsten Rüther teaches African History at the University of Vienna. She has a long-standing interest in the histories of old and new Christianities in sub-Saharan Africa, with an empirical focus on South and Southern Africa. More recently she became engaged in urban studies within the context of which she currently heads an interdisciplinary project on colonial and postcolonial housing in Kenya, the Democratic Republic of Congo and Zambia. Kirsten Rüther considers herself a social historian with a strong inclination towards histories of the everyday. It is in this context that her research on biographies and life histories is grounded. 